\title{
Whitefringed Beetles, Naupactus (= Graphognathus) spp. (Insecta: Coleoptera: Curculionidae) ${ }^{1}$
}

Wayne N. Dixon ${ }^{2}$

\section{Introduction}

Naupactus leucoloma Boheman, the whitefringed beetle, was first collected in North America near Svea, Florida in 1936 (Buchanan 1939). This species and two others (N. minor (Buchanan) and $N$. peregrinus (Buchanan)) comprise the whitefringed beetle complex in North America (Buchanan 1947, Warner 1975). Whitefringed beetles are considered serious pests of many agricultural crops (Young et al. 1950) and have become pests of young pines planted on converted croplands in the South.

\section{Distribution}

Originally from South America (Argentina, Peru, Chile, Uruguay), whitefringed beetles are now widely distributed throughout the southern United States (AL, AK, FL, GA, LA, MO, MS, NC, SC, TN, TX, VA) and occur in New Zealand (Buchanan 1939, 1947; Warner 1975).

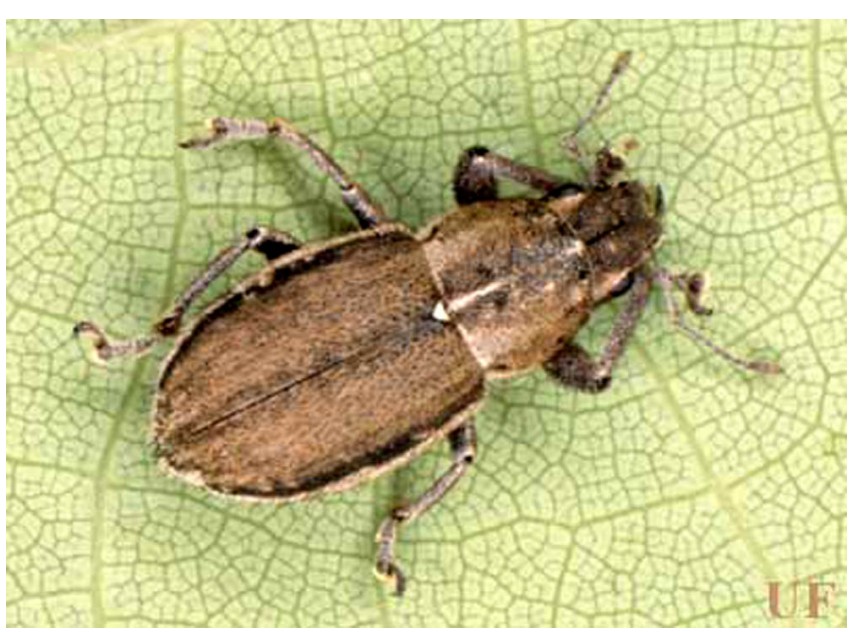

Figure 1. Dorsal view of an adult female whitefringed beetle, Naupactus sp. Credits: University of Florida

\section{Description}

Adult: Female (males unknown) light to dark gray or brown, with a lighter band along the outer margins of the wing covers, and two paler longitudinal lines on each side of the thorax and head, one above and one below the eye; length ca. $12 \mathrm{~mm}$. Flightless; underwings rudimentary, inner margins of outer wings fused together.

\footnotetext{
1. This document is EENY-294 (originally published as DPI Entomology Circular 309), one of a series of Featured Creatures from the Entomology and Nematology Department, Florida Cooperative Extension Service, Institute of Food and Agricultural Sciences, University of Florida. Published: June 2003. This document is also available on Featured Creatures Website at http://creatures.ifas.ufl.edu. Please visit the EDIS Website at http://edis.ifas.ufl.edu. Additional information on these organisms, including many color photographs, is available at the Entomology and Nematology Department website at http://entnemdept.ifas.ufl.edu/.

2. Wayne N. Dixon, Florida Department of Agriculture and Consumer Services, Division of Plant Industry, Gainesville.
}

The Institute of Food and Agricultural Sciences (IFAS) is an Equal Employment Opportunity - Affirmative Action Employer authorized to provide research, educational information and other services only to individuals and institutions that function without regard to race, creed, color, religion, age, disability, sex, sexual orientation, marital status, national origin, political opinions or affiliations. For information on obtaining other extension publications, contact your county Cooperative Extension Service office. Florida Cooperative Extension Service/Institute of Food and Agricultural Sciences / University of Florida / Larry R. Arrington, Interim Dean 


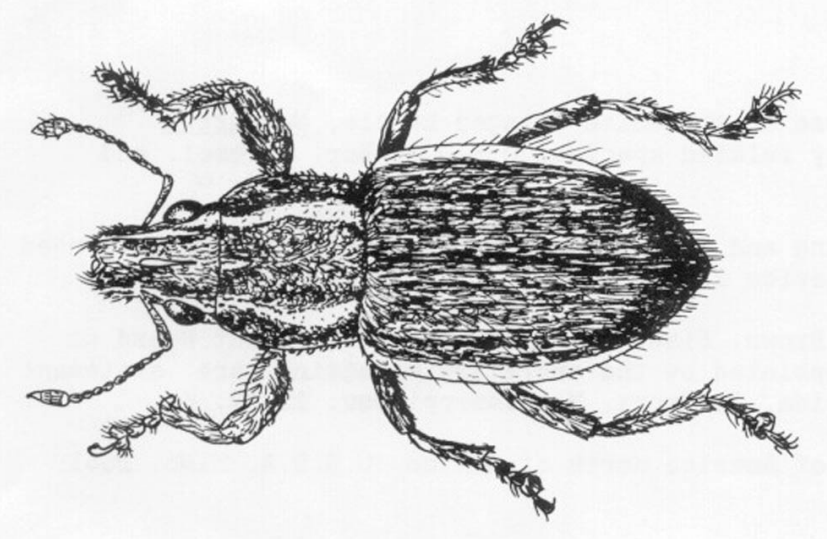

Figure 2. Adult female. (After Buchanan). Credits: Division of Plant Industry

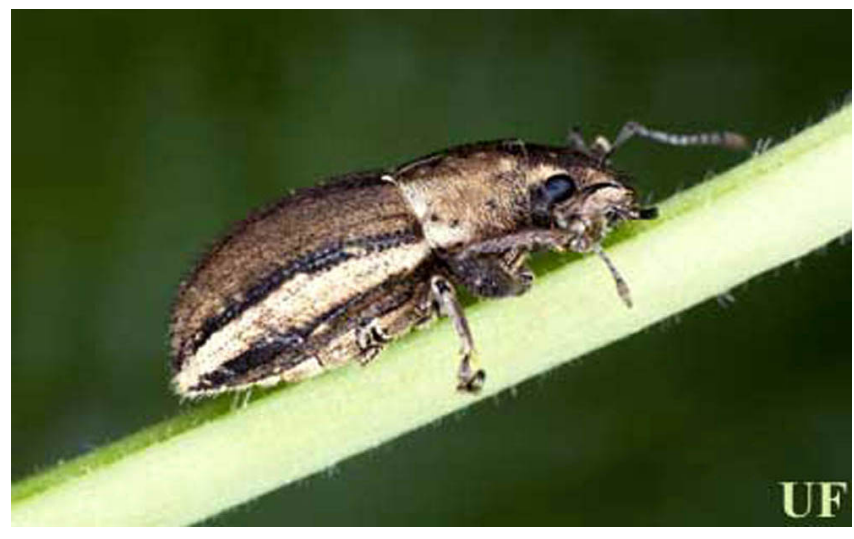

Figure 3. Lateral view of an adult female whitefringed beetle, Naupactus sp. Credits: James L. Castner, University of Florida

Egg: About $0.9 \mathrm{~mm}$ long X $0.6 \mathrm{~mm}$ wide; newly laid egg white, turning light yellow after four to five days.

Larva: Mature larva about. $12 \mathrm{~mm}$ long; creamy yellowish-white; $\mathrm{C}$-shaped with a strong thoracic swelling.

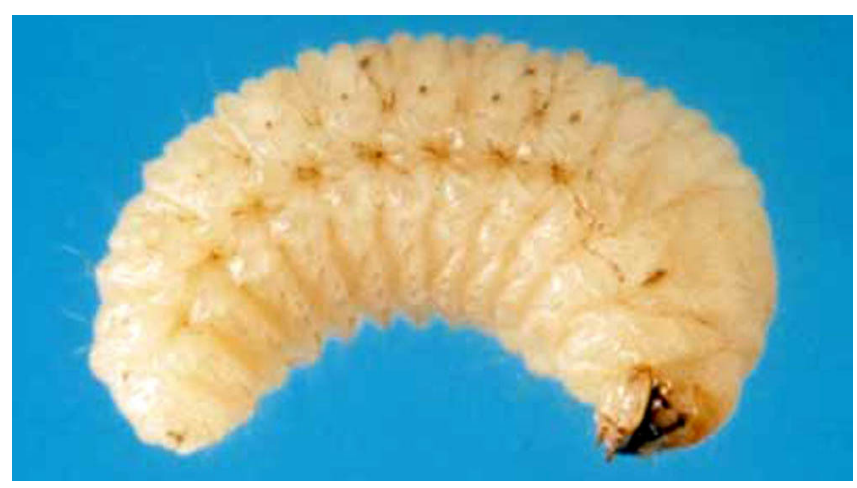

Figure 4. Larva of a whitefringed beetle, Naupactus sp. Credits: Wayne N. Dixon, Division of Plant Industry
Pupa: About $12 \mathrm{~mm}$ long; color creamy-white (Buchanan 1939, Young et al. 1950, Anderson 1938).

\section{Biology}

Adult beetles (univoltine $=$ one generation per year) emerge from the soil from May to October and feed on foliage. Oviposition (parthenogenetic reproduction) occurs five to 25 days after emergence. Egg masses (11 to 14 eggs) are laid on plant stems, roots, soil, and where they contact the soil onto hay, firewood, lumber, and farm tools and machinery. Eggs hatch 11 to 100+ days after oviposition (summer eggs average 17 days; winter eggs average 100 days). Larvae feed on roots, tubers, and underground stems as well as dead plant material and complete their development in the soil. Whitefringed beetles overwinter as larvae.

Pupation occurs from late April to late July in cells constructed by the larvae; however, some larvae spend a second year feeding on plants in the soil before they pupate. Most pupal cells are 5 to $15 \mathrm{~cm}$ below the soil surface; however, cells have been found at a depth of $36 \mathrm{~cm}$. In the summer months, the pupal stage lasts ca. 13 days; in cooler months it is longer (Young et al. 1950).

\section{Host Plants}

Whitefringed beetles have been associated with over 385 plant species. The most common hosts are cotton, peanuts, okra, velvetbeans, soybeans, cowpeas, sweet potatoes, beans, and peas (Young et al. 1950, Johnson and Tappan 1987). Adults seem to prefer plants with large, broad, smooth leaves; larvae feed on agricrop plant roots, newly germinated acorns and nuts, and the roots of woody plants (e.g., peach, pecan, tung, willow) (Young et al. 1950) and pines.

\section{Survey and Detection}

The results of root feeding by whitefringed beetle larvae can range from scattered areas of a few dead or dying plants within a field to nearly all plants being damaged. Examine roots of affected plants: larval feeding appears as small to large amounts of decortication or partial to complete removal of tap roots(s), below-ground portions of the stem, and some lateral roots. Sample for larvae during the 
months of August through May by removing ca. 0.3 $\mathrm{m} 3 /$ soil (ca. $15 \mathrm{~cm}$ deep) and sifting through soil sieves $8,16,24,40-\mathrm{mesh} / 2.5 \mathrm{~cm}$ screens).

\section{Management}

Considerable federal and state control efforts have been directed toward suppression of whitefringed beetles. Quarantine regulations were enacted soon after discovery of the beetles, yet the pests continued to spread. In 1940, ca. 409 acres of crops were damaged by whitefringed beetles in Florala, and by 1944 over 4,000 acres were damaged (Brown 1951).

\section{Chemical}

Various insecticides have been employed or tested to control whitefringed beetles (e.g., DDT (Brown 1951), carbaryl (Gross and Harlan 1975), diflubenzuron (Henzell et al. 1979), cryolite (Brown 1951), dieldrin, aldrin, and chlordane (Boutwell and Watson 1978)). Many of these are no longer legal for use, even by licensed applicators. Links to current management recommendations from the University of Florida are listed here.

Insect Management Guide for Field Crops and Pastures (http://edis.ifas.ufl.edu/TOPIC_GUIDE_ IG_Field_Crops_and_Pastures)

Insect Management Guide for Forests and Shade Trees (http://edis.ifas.ufl.edu/TOPIC_GUIDE_IG_ Forest_and_Shade_Trees)

Insect Management Guide for Fruit and Nuts (http://edis.ifas.ufl.edu/TOPIC_GUIDE_IG_ Fruit_and_Nuts)

Insect Management Guide for Ornamentals (http://edis.ifas.ufl.edu/TOPIC_GUIDE_IG_ Turf_and_Ornamentals)

Insect Management Guide for Vegetable Crops (http://edis.ifas.ufl.edu/TOPIC_GUIDE_IG_ Vegetables)

\section{Cultural}

Practices include: (1) planting oats or other small grains, which are much less preferred by the beetles due to their fibrous root systems; (2) limiting acreage planted to summer legumes (e.g., peanuts, soybeans) and placing leguminous crops on a three to four year rotation. The persistence of whitefringed beetle populations in an area of land is noteworthy and speaks for the difficulty of achieving control. In some parts of Florida, pine plantations on converted agricrop land (particularly with soybean, peanut, cotton cropping histories) have failed, not only on land with no fallow period between agricrop and pine, but also up to three to four years after the last agricrop planting.

\section{Selected References}

Anderson WH. 1938. A key to separate the larvae of the white-fringed beetle, Naupactus leucoloma Boh., from the larvae of closely related species. USDA Bureau of Entomology and Plant Quarantine Circular E-422. 3 p.

Boutwell JL, Watson DL. 1978. Estimating and evaluating economic losses by white-fringed beetles on peanuts. Bulletin of the Entomological Society of America 24: 157-159.

Brown AC. 1951. Statement of Arthur C. Brown, Plant Commissioner, State Plant Board of Florida before special study committees appointed by the secretary of agriculture: statement in re white-fringed beetle control in Florida. Gulfport, Mississippi, Nov. 15-17. $6 \mathrm{p}$.

Buchanan LL. 1939. The species of Pantomorus of America north of Mexico. USDA Miscellaneous Publications 341: 1-39.

Buchanan LL. 1947. A correction and two new races in Graphognathus (white-fringed beetles) (Coleoptera: Curculionidae). Journal of the Washington Academy of Science 37: 19- 22.

Gross HR, Jr, Harlan DP. 1975. Evaluation of preventive adulticide treatments for control of whitefringed beetles. Journal of Economic. Entomology 68: 366-368.

Henzell RF, Lauren DR, East R. 1979. Effect on the egg hatch of white-fringed weevil (Graphognathus leucoloma) of feeding lucerne (Medicago sativa) treated with the insect growth 
regulator diflubenzuron. New Zealand Journal of Agricultural Research 22: 197-200.

Johnson F, Tappan WP. 1988. Field crops and pastures. pp. IV D-1-25 in 1988 Florida Insect Control Guide. Institute of Food and Agricultural Sciences, University of Florida, Gainesville, Florida.

Warner RE. 1975. New synonyms, key, and distribution of Graphognathus, whitefringed beetles (Coleoptera: Curculionidae), in North America. USDA Cooperative Economic Insect Report 25: 855-860.

Young HC, App BA, Gill JB, Hollingsworth HS. 1950. White-fringed beetles and how to combat them. USDA Circular 850: 1-15. 